Citation: Sibul, K. (2020). Glimpses into the History of Interlingual Simultaneous Theater Interpreting in Estonia. Journal of Audiovisual Translation, 3(2), 170185.

Editor(s): A. Matamala \& J. Pedersen

Received: January 30, 2020

Accepted: July 22, 2020

Published: December 21, 2020

Copyright: (C2020 Sibul. This is an open access article distributed under the terms of the Creative Commons Attribution License. This allows for unrestricted use, distribution, and reproduction in any medium, provided the original author and source are credited.

\section{Glimpses into the History of Interlingual Simultaneous Theater Interpreting in Estonia}

\author{
Karin Sibul ${ }^{\varpi}$
}

University of Tartu

\begin{abstract}
This paper examines the practice of simultaneous interpretation of theater performances, in particular between Estonian and Russian, in Estonia over 70 years. This type of interpreting has not received much scholarly attention; rather, studies have mostly focused on the sign language interpretation of theater performances for the deaf community. I conducted interdisciplinary historical research relying on the oral history method to help preserve the fast-disappearing oral heritage of theater interpreting. This paper distinguishes between two periods in theater interpreting in Estonia, as determined by two drastically different sociopolitical periods in Estonia's history. Drawing upon a total of 88 interviews with interpreters, people who recruited interpreters, and audience members, I identified and interviewed a total of 15 theater interpreters. I also analysed newspaper articles and performance schedules, which usually yielded single-word mentions of interpretation having taken place. This paper examines answers to the questions of who interpreted what, how, and when, and reaches the conclusion that theater interpreting can be a tool to bridge a gap between two communities as well as to facilitate integration in the same cultural space.
\end{abstract}

Key words: simultaneous theater interpreting, sign language theater interpreting, interpreter-mediated performance, historical research.

sibulkarin@gmail.com, https://orcid.org/0000-0002-1434-829X 


\section{Introduction}

This article discusses the diachronic evolution of the simultaneous interpretation of theater performances between Estonian and Russian in two drastically different sociopolitical periods, which correspond to periods in Estonia's history: Soviet Estonia-i.e., Estonia occupied by the Soviet Union from 1944 to 1991-and the once again independent Republic of Estonia, since 1991. The objective of my study, in addition to mapping the evolution of interpretation in Estonia, is also to help preserve the fast-disappearing oral heritage of interpretation, "a socially situated practice" (Inghilleri, 2005, p. 126). I have attempted to identify interpreters and find factual evidence to corroborate the use of theater interpreting between Estonian and Russian in Estonia.

Theater interpreting is a form of interlingual simultaneous interpretation that makes the performance accessible to those audience members who do not master the original language of the performance. The simultaneous interpreting of theater performances for the benefit of audience members not fluent in the source language is a largely unrecognized but highly specialized area of interpretation that responds to the need to integrate an increasingly mobile international community.

In Estonia, the simultaneous interpretation of performances from Estonian into Russian has a long tradition dating back to 1951 (Barsova, 1954). This type of interpretation has not received much attention from researchers or from theater critics and reviewers, neither in Estonia nor elsewhere. Studies in Europe, the United States, and Australia have mostly focused on the sign language interpretation of theater performances for the deaf community (Gebron, 2000; Griesel, 2000; Turner \& Pollitt, 2002; Napier, McKee, \& Goswell, 2010; Richardson 2017; Richardson \& Thompson, 2018).

In sign language interpretation, theater translation (Griesel, 2000)-also known as theatrical interpreting (Gebron, 2000; Richardson, 2017), performing arts interpreting (Campbell, 1998; Peterson, 1998), artistic interpreting (Sign on Stage, 1998), theater interpreting (Rocks, 2015; Turner \& Pollitt, 2002), and performance interpreting (RID Standard, 2015)-is defined as "the signed translation of a dramatic text performed in English" (Napier, McKee, \& Goswell, 2010, p. 137). This can, however, apply not just to English but to any language. The performance is thus made accessible to the hearing-impaired or deaf audience. The translation of drama is considered "fundamentally different in nature" from that of other types of text (Windle, 2011, p. 153). Julie Gebron tries to answer the question of what theatrical interpreting is: "It is a new form of art. It is not merely translating words; it is creating a work of art" (2000, p. 5). Irina Bondas, in her research on simultaneous interpretation of theater performances (2013), she discusses in great detail the difficulties and reasons why there is terminological and theoretical confusion. She recommends researching theater interpreting within the field of interpreting studies (pp. 58-59).

In the context of this article, "theater interpreter" refers to a simultaneous interpreter who interprets theater performances, and "theater interpreting" to the interpreting thereof (Sibul, 2017). 
This article provides a historical overview of theater interpreting in Estonia over a 70-year period by providing the background to the circumstances in which interpretation was introduced (section 2) and describing the analytical methods used (section 3). Theater interpreting during two distinct periods of Estonia's sociopolitical history is then examined (sections 4 and 5), looking at interpreting from Estonian into Russian (subsections 4.1 and 5.1) and interpreting from Russian into Estonian (subsections 4.2 and 5.2), as well as at the interpreters themselves (subsections 4.3 and 5.3).

\section{Background}

Distinct sociopolitical environments in any given period determine how interpretation is positioned in society, as well as the need for interpreting services during that period. Theater interpreting originated due to the changing political environment after World War II.

The inflow of Russian speakers started immediately after Estonia's occupation by the Soviet Union in 1944. Estonia lost its monoethnicity when a Russian-speaking working class was imported, preceded by the mass deportation of Estonians to Siberian labor camps and prisons (Aarelaid, 2008, p. 73). The percentage of Russians in Estonia leaped from 8.2\% in 1934 to 30.3\% by the time of the 1989 census (Vare, 1999, pp. 72-89). Between the two World Wars, Estonia was considered the most homogeneous of the three Baltic countries (Zetterberg, 2011, p. 400), with Estonians making up about $90 \%$ of the country's population in the 1930s (Raun, 1991, p. 130); this shrank to $61.5 \%$ by 1989 (Vare, 1999, pp. 72-89). However, Soviet nationality policy "failed to stop indigenous inhabitants identifying themselves as Estonians. Indeed, it inadvertently strengthened this identification by making ethnicity the most salient identity marker for most citizens" (Mole, 2012, p. 67).

As a result of all this, the linguistic environment changed in Estonia. Now there were two distinct communities: people communicating in Estonian and people communicating in Russian. A change in the linguistic-demographic situation created a need for simultaneous interpretation between Estonian and Russian (Sibul, 2018).

The Constitution that the Soviets enforced in Estonia in 1944 abolished the concept of the state language. Language has always been more than a simple tool for communication: it has also been a mark of national prestige (Delisle, 1999, p.2). To curb this prestige, the USSR Council of Ministers passed a secret decree in 1978 on the learning and teaching of Russian in the Soviet republics, the primary aim of which was to limit the use of local languages such as Estonian in public settings and to ensure the penetration of Russian (ERAF.1.4.5353.I. 1-3, 40-44). The title of the decree, "Measures to Further Improve Teaching and Learning Russian in the Soviet Republics," refers to the problematic situation of Russian in the Soviet Union: in many republics, the indigenous population had not switched to Russian and did not communicate amongst itself in Russian. Arguably a mere 29\% of Estonians were fluent in Russian, according to the 1970 census (Laanemäe, 2013, p. 201). 
On 22 December 1978, the Central Committee of the Estonian Communist Party passed a relevant resolution including a detailed long-term action plan for the implementation of the 1978 decree (Lõhmus, 1999, pp. 142-146). Both documents were classified as confidential. The direct impact of the 1978 decree was to limit the use of Estonian under the guise of mandatory bilingualism, which sought to enforce the use of Russian in all domains and achieve a gradual switch to Russian monolingualism.

Theater interpreting was introduced in Estonia after World War II under the changed political order, with the interpreting of performances from Estonian into Russian for the benefit of a monolingual Russian-speaking working class population of about 400,000, compared to fewer than one million Estonians. Three theaters provided interpretation regularly: two throughout the season and the third during the so-called summer season, which lasted one month. In 1948, a Russian-language state theater was founded for the Russian population, at which just a few performances were interpreted from Russian into Estonian.

Archival research failed to uncover any documents (such as legislative acts, theater directors' directives, etc.) attesting to the introduction of theater interpreting in Estonia.

In the late 1980s, the sociopolitical situation gradually started to change, and Estonia passed the Language Act in 1989 to restore the status of the Estonian language. The Republic of Estonia regained independence on August 20, 1991. The 1992 Constitution stipulated Estonian as the state language.

Over the 70 years under review, the number of Estonian-language repertory theaters varied from around 10 to 12 . The only Russian-language theater has experienced difficulties until recently; in particular, it had low audience numbers due to poor repertoire policy (see subsections 3.2 and 4.2). Out of 20 theater interpreters who were interviewed for this research, three have interpreted for more than 40 years; two of them were staff interpreters.

Arising from two drastically different political orders, theaters operated under different names. In total the simultaneous interpretation of theater performances took place in seven theaters (up to 1991), as is evidenced by interviews, archival documents, newspaper articles, and performance schedules published in newspapers. Performances were interpreted from Estonian into Russian at the Tallinn State Academic Drama Theater, named after Viktor Kingissepp (renamed the Estonian Drama Theater in 1989), the Vanemuine State Academic Theater in Tartu (renamed the Vanemuine Theater in 1989), and the Pärnu Drama Theater, named after Lydia Koidula (renamed the Endla Theater in 1988). A few selected performances were also interpreted at the ESSR State Youth Theater (renamed the Tallinn City Theater in 1994), the Viljandi Ugala Drama Theater (since renamed the Ugala Theater), and the State Academic Estonia Opera and Ballet Theater (renamed the National Opera Estonia in 1998).

At the State Russian Drama Theater (known as the Russian Theater since 2005), a few performances were interpreted from Russian into Estonian. 
As the above-mentioned theaters were also used as conference venues until 1991, all seats were equipped with sockets to plug in headsets. ${ }^{1}$ Headsets were available in the cloakroom free of charge. On the cloakroom wall, there was a sign informing the audience that it was possible to listen to interpretation into Russian. Audiovisual evidence (newsreels, film clips, photos) portrays the use of simultaneous interpreting at various other events held in the theater halls, as well as different models of headsets in use and audience seating arrangements. Although I uncovered no audiovisual evidence of interpreting at a theater performance, images corroborated its technical availability, with people using headsets seen throughout the hall (Sibul, 2018).

\section{Methods and Materials}

I chose to conduct an interdisciplinary study, carrying out historical research using ethnographic and content analysis methods for the material gathered. As regards theater interpreting, I looked for answers to questions about who interpreted how, where, and when inspired by "what, how, where, when, for whom and with what effect," as suggested by Anthony Pym (1998, p. 5) for translation history, and later expanded upon by Lieven D'hulst (2001). This research approach is similar to archaeology, as defined by Pym. With few historical records available in archives, oral history was the best applicable method. I verified the information uncovered in interviews against information from performance schedules, newspaper articles, and archival documents. Content analysis helped to analyze written texts (newspaper articles, performance schedules) and communication-related artifacts that can be turned into texts (transcriptions of interviews, audiovisual evidence).

My goals when recruiting interview participants were to identify and interview as many interpreters as possible to gain information about the early years of interpretation use in Estonia, and to avoid oversaturation. It was important to act quickly, as those who worked in the post-war period are now reaching a critical age.

The use of qualitative interviews allowed me to gather in-depth information. According to Sarah J. Tracy, interviews and archival research supplement one another: interviews play a significant role in examining topics that "cannot be observed or efficiently accessed" or that "may otherwise be hidden or unseen" (2013, p. 132-133). As explained above, written sources about interpretation are scarce, as it has been considered quite marginal compared to other activities. Hence, "interviews are especially helpful for acquiring information that is left out of formal documents," such as in the case of this study (Tracy, 2013, p. 133). Interviews are also one of the most efficient tools in gathering external data, to stimulate memory.

For the first period under review, I conducted 69 interviews: 30 with interpreters and 39 with people who recruited interpreters or benefited from interpreting. These semi-structured interviews were what led me to 11 interpreters who had interpreted for the theater. The semi-structured approach

\footnotetext{
${ }^{1}$ See more about technology in Sibul, 2018.
} 
provides sufficient flexibility for the interviewees to recall and to express their thoughts and ideas (Hale \& Napier, 2013, p. 97). To keep the interviews on track and to prevent interviewees from getting sidetracked by vague recollections and lengthy storytelling, I prepared a questionnaire of 10 to 15 open-ended questions, called an interview guide (Tracy, 2013, p. 139). I deduced my role as an interviewer to be that of a listener, prompting the interviewees and keeping them on track with such occasional open-ended questions (Seidman, 2006).

For the second period, I interviewed 19 people, of whom four were theater interpreters who interpreted between Russian and Estonian in both directions if necessary; five interpreted between other languages at the theater and sometimes from Russian into Estonian. One of the interpreters Maia Soorm - interpreted during both periods. As my aim was to put together a more comprehensive picture of the theater interpreting landscape, I included ten audience members in my interviewee pool: four theater critics who had seen performances during both periods, and six users of theater interpretation (their ages ranging from 11 to 73). The impressions of these audience members added value to the information gathered and allowed for triangulation. For the purposes of this paper I will not explore how interpreting was perceived any further as the sample is not representative and as most of those who listened to interpreting had no previous experience with interpreting and gave quite vague answers.

The interpreter pool-11 (1944-1991) and 9 (since 1991) - met the criteria recommended in research literature-sufficiency and saturation of information-leading to me hearing the same information from several different sources (Seidman, 2006; Hale \& Napier, 2013).

\section{Theater Interpreting (1944-1991)}

In terms of setting, interpretation in Estonia after World War II existed in both inter-social and intrasocial settings. This is a first comprehensive analysis of theatre interpreting in Soviet Estonia. For linguistic reasons, I discuss interpretation in two language-based subgroups: Russian and Estonian languages as source and target languages of interpretation. The basis for my approach was that given the influx of monolingual Russians to Estonia, interpretation between Russian and Estonian was needed to facilitate communication under unexpectedly changed socio-political circumstances; this meant interpretation was used at various public events, including the theatre.

\subsection{Theater Interpreting from Estonian into Russian}

Performances were interpreted from Estonian into Russian in seven theaters, three of which provided interpretation regularly, as is evidenced by my research (Sibul, 2017).

Arguably the Vanemuine Theater, which put on drama, ballet, and opera productions, was the first theater in the Soviet Union to introduce interpreting (1951/1952 season), and it provided simultaneous interpretation of plays into Russian for about 44 years, until 1995 (V. Barsova, personal 
communication, June 12 , 2013). During the first season, the interpreter was temporarily tasked with also interpreting operas. This was because the monolingual Russian theater director dispatched to the theater from Moscow wanted the Russian-speaking audience to understand the operas (even if the synopsis was available in the program). This tradition was immediately discontinued when the Russian theater director returned to Russia. The director had also tested using two interpreters to differentiate between male and female voices. This experiment, however, was short-lived.

Interpretation at the Tallinn State Academic Drama Theater continued for 60 years, longer than at other theaters. The start of the tradition is evidenced by an article published on January 12, 1952 (“TR Draamateatri etendused tõlgitakse vene keelde," 1952, p. 2).

Two theaters - the Vanemuine in Tartu and the Drama Theater in Tallinn-provided interpretation for nearly all drama performances during the season (Karja, 2017, p. 166), whereas the third, the Pärnu Drama Theater, did so during the so-called summer season. Simultaneous interpretation at the theater in Pärnu was introduced under quite different circumstances. Pärnu was a well-known summer resort town with numerous full-board resorts and holiday homes, which attracted holidaymakers from all over the Soviet Union, including a fair share of Russian and Jewish intellectuals. Upon the completion of the new theater building in 1967, the so-called summer season for holidaymakers was introduced. During one summer month, all of the performances were simultaneously interpreted into Russian (Talts, 2000, p. 230). In the summer of 1980, a total of 34 performances were held over a month, "all interpreted into Russian" (Laos, 1980, p. 11). Sometimes more than half of the audience listened to the interpretation (Aaloe, 1988, p. 6). Reviews of the summer season usually include a sentence acknowledging that visitors to Pärnu received an "objective glimpse of the state of the theater" (Kruus, 1975, p. 7), as the town did its utmost "to make multilingual holidaymakers' summer evenings more enjoyable so that each of them would find their way to the theater" (Laos, 1981, p. 9).

\subsection{Theater Interpreting from Russian into Estonian: The State Russian Drama Theater (1948-91)}

There is also factual evidence that interpretation of performances from Russian into Estonian took place in the only Russian-language theater in Estonia, the State Russian Drama Theater, founded under the changed political circumstances in December 1948.

According to the performance schedules published in the cultural weekly, a few performances were interpreted from 1958 to 1963, and again in 1990. The first reference to interpretation is from January 5, 1958: there was just one interpreted performance during the entire year (Performance Schedule, 1958, p. 8). There were three in 1959 and 1962, two in 1963, and 22 in 1990. No proof exists that interpretation took place in other years. I have been unable to establish why interpretation of the performances was introduced or discontinued at this theater. Circumstantial evidence points to the sociopolitical environment (to expose the Estonian audience to a different-i.e., Russiantheatrical language and style of acting), technical issues (availability, quality, and cost of interpreting 
equipment), administrative issues (management decisions), and language policy (steps taken to introduce bilingualism; i.e., to enforce the learning of Russian in preparation for a total switchover to Russian).

The Russian Drama Theater experienced many difficulties (Kekelidze, 2007). It was a closed world, living its own life, lacking an audience and using second-rate stage directors from Moscow (Kulli, 2003, p. 4). The local press lost any interest in covering its productions: it was called "the conspiracy of silence" (Yantchek, 1998, p. 97). Viewers were clearly indifferent, with merely a quarter of the hall filled (Kekelidze, 2007, p. 8); occasionally just 50 to 60 people were present (Romanovitch, 1971, p. 63). A theater critic from Moscow, however, admitted that there was one play "that people [went] to see even on weekdays" (Romanovitch, 1971, p. 67). Despite this, his overall judgment was devastating, and he said the theater needed "to overcome infantilism" and that the repertoire selection was questionable, the quality of acting poor, and attendance figures low. This led to criticism in leading local Russian newspapers, which repeatedly discussed the poor production quality (Romanovitch, 1971, p.68). An article with the revealing title "A Road to Nowhere?" does a good job in describing the state of the Russian theater in Estonia (Kekelidze \& Tuch, 1986, p. 2). In addition to weak productions, the overall atmosphere in the theater was very negative (Yantchek, 1998, p. 98). Viewers complained to editorial boards as well as to various institutions. Any criticism was fiercely resisted and led to further complaints by actors against newspapers, including a letter sent to the communist party headquarters in Moscow. Even the cultural biweekly "Soviet Culture," published in Moscow, got involved (Vladimirova \& Govorushko, 1987, p. 2). "The situation is alarming", concludes a theater critic (Teatriankeet, 1985, p. 50). Artistic directors changed every few years, and for years, there simply was not one (Kekelidze, 2007). The simultaneous interpretation of performances which not even the local Russian population cared to see, may have been the least of the theater's concerns. My guess is that the underlying cause for not considering interpretation was related to the theater's internal problems.

In 1990, the increased number of interpreted performances could be explained by the changed political landscape: Estonia was taking its first steps towards breaking loose from the Soviet Union.

\subsection{Interpreters}

During the period from 1951, when theater interpreting was introduced, until 1991, three theater interpreters had worked in their respective theaters for years: Valeria Barsova (1928-2013) at the Vanemuine and Maia Soorm (b. 1950) at the Drama Theater in Tallinn were staff interpreters, and Malle Shalda freelanced at the Pärnu. They interpreted from Russian into Estonian and occasionally from Estonian into Russian when Estonian theaters toured elsewhere in the Soviet Union. The discussion below is based on a pool of 11 interviews. Barsova, Soorm, and Shalda were competent in their field and interpreted performances for over 40 years. While none received any interpreter training, they therefore had decades of practice. They all got their job by chance. Two of them were employed as full-time interpreters by the theaters in Tallinn and Tartu and interpreted 
several nights a week and frequently as many as six or seven. Shalda, who worked at Pärnu, was working as a Russian teacher when she was first invited to interpret, and she continues both to teach and interpret to this day (M. Shalda, personal communication, May 26, 2015).

To describe the start of her career, Barsova said that the monolingual Russian theater director auditioned her, liked her voice, and employed her on the spot to start interpreting performances at the theater, thus introducing simultaneous interpretation of theater performances to the Soviet Union (V. Barsova, personal communication, June 12, 2013). Indeed, Barsova was arguably the first theater interpreter in the entire Soviet Union (Jürimäe, 1988).

Barsova concluded in her interview that, when touring outside Estonia elsewhere in the Soviet Union, she was the center of attention and was praised for her clear diction, for which she was also commended in a review in a Moscow paper (V. Barsova, personal communication, June 12, 2013). The article, entitled "A Voice in the Headset," ran in the renowned Russian cultural weekly Literaturnaya Gazeta and outlined the specificity of an interpreted performance: "An announcer becomes a mediator between the cast and the audience, reading out the text. The success or failure of the performance depends largely on the voice in the headset" (Razorenova, 1976, p. 4).

Maia Soorm was the staff interpreter for 37 years at the Drama Theater until 2012, when she left the theater and the tradition was discontinued. She recalled that when she received the job of interpreter only a couple of hours before the start of her first performance, Voldemar Panso (1920-1977), a renowned Estonian director and actor, gave her two sound pieces of advice: firstly, to come to the theater about an hour before the start of the performance, go into the makeup room, see what condition or mood the cast members were in and, if possible, exchange a few words with them; secondly, that it was an easy job: the actor or actress would speak Estonian on the stage and the interpreter would say the same thing in Russian as best she could, at the same time as the actor or actress. "You speak when he or she speaks; if he or she has nothing to say, you keep quiet as well": thus, Soorm summarized Panso's advice (M. Soorm, personal communications, November 1, 2011; January 28, 2012). With a university degree in Russian, Soorm had no formal interpreter training and learned all the necessary skills on her own. Her seminal professional work was recognized in 2010 when the Estonian Theater Union awarded her the Aleksander Kurtna Prize for her long-term dedication to theater interpreting for interpreting performances into Russian in "an artistically enjoyable manner, maintaining the pace and register dictated not only by the written text but also by the nature of the performance and by the actors" (Kurtna Prize, 2010).

Another two theater interpreters (an actress and a theater support staff member who had studied at the theater studio and at times was a supporting actress) interpreted occasionally when necessary in the 1970s and 1980s. Based on their interviews, they did not comprehend the essence of theater interpretation. The actress interpreted simultaneously without a prepared text and the supporting actress simply read the text. Both admitted that if they lost track of the text, they just skipped portions of it and continued from where they could pick up again. Yet another six interviewees who 
held different jobs and interpreted regularly at other events interpreted performances just once or twice.

A former interpreter who had interpreted just two performances in the 1980s summarized the experience as trivial and easy. Having the translated script in front of him, he had but to read it, taking care not to make any mistakes in his delivery. Another interpreter recalled timing - that is, reading the correct sentence at the right time-as the biggest problem, as the actors did not always stick to the original script. An interviewee who had never interpreted at the theater was convinced that theater interpreting could not be linguistically difficult, if one was used to interpreting fast speakers. Another admitted that his experience interpreting for the theater opened his eyes to what was done with classical plays and to how they were adapted, distorted, and updated, making it impossible to use the original translation of the play. Two interviewees looked at it as a side job they did when asked.

These six interpreters equated theater interpreting to simply reading a prepared text aloud. For them it was just another assignment and the only interpretation issue seemed to be how to synchronize their reading speed with the actors' speaking speed. They did not seem to comprehend the nature of their task when interpreting at the theater. The experiences of the three long-term theater interpreters yielded a more comprehensive picture of the nature of the job. For this research, they are also of greater significance, since they developed long-term relationships with their theaters. Two of them continue to interpret performances to this day.

The professional background of theater interpreters was diverse (full-time vs. freelancers; officials, editors, journalists), but there were also differences in how they were referred to at the theater (they were variously listed as an announcer, a transmitter, a prompter, an announcer-interpreter, and an announcer-transmitter). For example, one of the interpreters (now deceased) worked as a supplier for a radio manufacturing factory (ERA.R.2219.1.4.). For the guest performances in Moscow he was listed as a support actor (ERA.R.2219.1.4.).

Although I was able to gather information about interpreters working from Estonian into Russian, it still remains unknown who interpreted performances from Russian into Estonian at the Russian Drama Theater.

\section{Theater Interpreting (since 1991)}

As mentioned before, in August 1991, the Republic of Estonia reclaimed its independence. Under changed circumstances, with numerous ongoing reforms in every sphere of life and a cut in funding, the importance of theater interpreting seems to have fallen, at least for a while. However, since the turn of the century drama festivals and guest performances have increased demand for interpreting services and one of the theaters has employed a full-time simultaneous interpreter of the Russian language. 


\subsection{Theater Interpreting from Estonian into Russian}

The Vanemuine discontinued the tradition of theatre interpreting. The theater in Pärnu dropped the practice of summer seasons as the number of Russian-speaking holidaymakers fell drastically when Estonia left the Soviet Union. The Estonian Drama Theater stopped regularly interpreting performances in 2012.

State-of-the-art technology and revised accessibility standards have recently affected Estonia's theater interpreting landscape. Since the country's accession to the European Union in 2004, the Estonian Integration Foundation has launched a number of integration projects, such as the "Development of common cultural space through joint activities" $(2010,2011)$ and the European Social Fund's subproject "Activities supporting integration in Estonian society" (2016), to finance interpreting and acquire interpreting equipment. Three theaters preferred to test different modern surtitling solutions (iPads, smartphones), whereas the Estonian Drama Theater and Russian Theater focused on providing simultaneous interpreting. While interpreting from Estonian into Russian is in decline, interpreting into Estonian has risen as theater festivals have gained in popularity: guest companies from many countries bring in performances in different languages, thus necessitating interpretation into Estonian (and occasionally into Russian). Since 2004, the Golden Mask Theater Festival has taken place in Estonia, offering a selection of the best performances from Russian Federation theaters. Although called a festival, it actually comprises a number of Russian theaters touring in Estonia. Performances are simultaneously interpreted from Russian into Estonian.

\subsection{Theater Interpreting from Russian into Estonian: the Russian Theater}

The difficulties experienced by the Russian Theater (see 3.2) continued after Estonia regained its independence. Internal conflicts and managerial mistakes led to an intervention by the Minister of Culture in 2012. Just like decades ago, the hall was still half empty, and a mere 79 performances were held that year (Kund, 2012). The subsequent management change led to improved production quality and human relations and to a better atmosphere, and theater attendance increased (Vene Teatri juht, 2017, p. 9). To further increase attendance numbers and to introduce the non-Estonian population to the performing arts, the theater is going to introduce interpreting from Estonian into Russian for the guest performances by Estonian theaters frequently held on the premises of the Russian Theater, so that it becomes a multilingual theater cultural center (Vene Teater, 2016).

In terms of interpretation, the Russian Theater has occasionally interpreted performances since 1991. In 2011, the Integration Foundation allocated funds to the theater to interpret performances into Estonian, in order to promote a common cultural space (Uudised, 2011). Under the changed management, the theater opted for simultaneous interpretation. As part of the changes, the Russian Theater has now acquired new state-of-the-art simultaneous interpretation equipment (Vene Teater, 2016), and in 2017 advertised a competition to recruit a simultaneous interpreter to interpret theater performances. The job description reads as follows: 
The interpreter will read a prepared text. As the spectator expects each line to be interpreted, the interpreter will have to be able to improvise when interpreting and to respond quickly to situations when the actors improvise or deviate for whatever reason from the previous text. The candidate must interpret performances from Russian into Estonian and if possible Estonian-language guest performances into Russian, prepare texts for simultaneous interpretation (if the original Estonian text is amended in rehearsals), commission and edit texts for simultaneous interpretation, and coordinate simultaneous interpreting-related activities. (Vene Teater, 2017)

The effort to use simultaneous interpretation is noteworthy, considering that just a few years ago, an Estonian theater critic compared going to the Russian Theater to a blind date for an Estonian theater goer, admitting her surprise that "there is an Estonian audience present; at least on the first night earphones were used (the performance was simultaneously interpreted)" (Johannes, 2012, p. 20). A good theater interpreter may make the audience forget their headsets and the linguistic barrier (Sibul, 2017).

\subsection{Interpreters}

For the period since 1991, I interviewed nine people who have interpreted performances simultaneously: four from Russian into Estonian, four from other languages (Latvian, Greek, and English) and occasionally also from Russian into Estonian, and one from Latvian into Russian. They represent a variety of professions (dramaturge, artist, designer, support staff, poet, researcher, actress, theater interpreter, etc.). Relevant for this period is also Soorm who was interviewed for the previous period (see subsection 3.3) but continues to interpret and mentor to this day. The four interpreters of Russian and Soorm are all directly connected to the theater: three are employed by theaters as a member of the support staff, as a bilingual actress, and as a freelance bilingual actress, one is retired from the Estonian Drama Theater but interpreted for over 40 years (Maia Soorm), and the last became a full-time interpreter at the Russian Theater in 2017. Interpreters who mostly work into languages other than Russian interpret rarely-maybe just once in a while for a guest performance or at a festival. None of the interviewees except the bilingual actress have interpreted simultaneously without the text. The support staff member admitted that although she worked at the theater, she rarely attended rehearsals because she had other chores to attend to. She always used texts translated by translators, occasionally adjusting a word or two. She followed the text and did her best to catch up with the improvised scenes. The full-time theater interpreter employed by the Russian Theater has a permanent relationship with the theater: she can attend rehearsals and follow the production process. Several interviewees mentioned Maia Soorm as a role model and a mentor who advised them on how to do the job properly. It emerged that all the theater interpreters started just by chance, having a necessary language combination but no understanding of simultaneous interpretation skills. When asked whether they interpret or read the text, the interviewees fell into two groups: five called the activity interpreting and four said it involved reading the translated text. 


\section{Conclusion}

The history of interpreting in Estonia is a puzzle composed of little pieces, fragments of an activity that has often been overlooked by historians. Theater interpreting is another fragment that helps complete the picture and highlights an otherwise invisible field of activity. When researching this type of interpreting, historic research and oral histories are appropriate.

The simultaneous interpreting of theater performances between Estonian and Russian has a long tradition but is a field that so far has been underexplored in Estonia. My research is the first to use audiovisual sources to argue the case for interpretation in Estonia, confirming that theater halls had the necessary interpreting equipment. Archival research yielded factual evidence that theater interpreting started in 1951 at the Vanemuine Theater in Tartu, while arguably launching the tradition thereof in the entire Soviet Union. A total of 88 interviews with interpreters, people who recruited interpreters, and audience members helped me to map theater interpreting in Estonia, as did performance schedules: who interpreted how, where, and when. The pool of interviewees yielded the names of 20 theater interpreters who were then interviewed for this research: 11 interpreted in the first period under review, 9 in the second period, and Maia Soorm (listed among 11 ) is the only interpreter who has actively interpreted in both periods. In total, at least 20 theater interpreters interpreted at seven theaters. Interpreters in both periods also worked other jobs whereas just three have been full-time theater interpreters. Recently the Russian Theater has benefited most from theater interpreting: low attendance numbers have been reversed. European Union funding to facilitate the sharing of a common cultural space has helped theaters obtain stateof-the-art interpreting equipment. Theater interpreting has brought different language communities together in the same cultural space, promoting integration. With my historic research into 70 years of theater interpreting in Estonia, the voice of Estonian theater interpreters has finally emerged from across the decades.

\section{References}

Aaloe, Ü. (1988, July 8). Pärnu teatri suvehooaeg [Theater summer season in Pärnu]. Sirp ja Vasar, p. 6.

Aarelaid, A. (2008). Vaimuelust Eesti NSV-s [Intellectual life in the ESSR]. In M. Oja (Comp.), Eesti Vabariik 90 (pp. 73-76). Tartu: Haridus- ja Teadusministeerium.

Barsova, V. (1954). Personal file (started 27/04/1954). The Vanemuine Archive.

Bondas, I. (2013). Theaterdolmetschen - Phänomen, Funktionen, Perspektiven [Theater interpreting - Phenomena, functions, perspectives]. Berlin: Frank \& Timme.

Campbell, K. (1998). Performing arts interpreting. VIEWS 15(5), 19.

Delisle, J. (1999). Introduction. In R. A. Roland, Interpreters as diplomats (pp. 1-6). Ottawa: University of Ottawa Press.

D'hulst, L. (2001). Why and how to write translation histories? Crop: Emerging Views in Translation History in Brazil, 6, 21-32. 
ERAF.1.4.5353.I. 1-3, 40-44. (1978). NSV Liidu Ministrite Nõukogu salajane määrus liiduvabariikidele 13. oktoobrist 1978, nr 835 "Abinõude kohta vene keele õppimise ja õpetamise edasiseks täiendamiseks liiduvabariikides" [USSR Council of Ministers' secret decree to Soviet Republics as of 13/10/1978 no. 835, Measures to further improve teaching and learning Russian in the Soviet Republics].

ERA.R.2219.1.4 (1957). Töötajate nimekirjad 25.10.1944-28.02.1957 [Staff lists 25/10.194428/02/1957].

Gebron, J. (2000). Sign the speech: An introduction to theatrical interpreting. Hillsboro: Butte.

Griesel, Y. (2000). Translation im Theater: Die mündliche und schriftliche Übertragung französischsprachiger Inszenierungen ins Deutsche [Translation in theater: The oral and written transmission of French-language productions into German]. Frankfurt/M.: Peter Lang.

Hale, S. \& Napier, J. (2013). Research methods in interpreting: A practical resource. London, New York: Bloomsbury Academic.

Inghilleri, M. (2005). The sociology of Bourdieu and the construction of the "Object" in Translation and Interpreting Studies. In Inghilleri, M. (Ed.), Bourdieu and the Sociology of Translation and Interpreting, 125-145. Special issue of The Translator, 11(2).

Johannes, M. (2012, March 23). Klassikakapsel [Classic capsule]. Sirp, p. 20.

Jürimäe, T. (1988, January 24). Kalender [Birthdays]. Edasi, p. 2.

Karja, S. (2017). Natalja Kuzjakina ja Eesti Teater [Natalja Kuzjakina and the Estonian theater]. In M. Pesti \& T. Kaugemaa (Comps.), Teatrielu 2016 (pp. 165-168). Tallinn: Eesti Teatriliit. Eesti Teatriagentuur.

Kekelidze, E. (2007). Stsena i vremja [Stage and time]. Aleksandra: Tallinn.

Kekelidze, E. \& Tuch, B. (1986, June 8). Po doroge v nikuda [A road to nowhere]. Sovetskaja Estonija, p.2.

Kruus, O. (1975, October 17). Pärnu teatris [At the theater in Pärnu]. Sirp ja Vasar, p. 7.

Kulli, J. (2003, December 13). Juubilarist Vene Draamateater vajab remonti ja publikut [Russian Drama Theater celebrates a jubilee but needs redecoration and audience]. Õhtuleht, p. 4.

Kund, O. (2012, July 10). Debatt kunstilise juhi üle tõi Vene teatrisse võimuvahetuse [A discussion about artistic leadership brought along a managerial change]. Postimees. Retrieved from https://www.postimees.ee/902832/debatt-kunstilise-juhi-ule-toi-vene-teatrissevoimuvahetuse

Kurtna Prize. (2010). Retrieved from http://www.teatriliit.ee/auhinnad/ laureaadid-aastate-jargi/ laureaadid-2010

Laanemäe, A. (2013). Kümme aastat valges majas [Ten years in the white house]. Tallinn: Argo.

Laos, U. (1980, July 18). Suvehooaeg Pärnus [Summer season in Pärnu]. Sirp ja Vasar, p. 11.

Laos, U. (1981, July 10). Pärnu teatri suvehooaeg [Theater summer season in Pärnu]. Sirp ja Vasar, p. 9.

Lõhmus, M. (1999). Toimetamine: kas looming või tsensuur [Editing: Creation or censorship]. Tartu: Tartu Ülikooli Kirjastus.

Mole, R. C. M. (2012). The Baltic States from the Soviet Union to the European Union: Identity, discourse and power in the post-Communist transition of Estonia, Latvia and Lithuania. London, New York: Routledge.

Napier, J., McKee, R., \& Goswell, D. (2010). Sign language interpreting: Theory and practice in Australia and New Zealand (2nd ed.). Sidney: The Federation Press.

Performance schedule. (1958, January 31). Sirp ja Vasar, p. 8.

Peterson, R. (1998). Performing arts interpreting, from Shakespeare to Shamu: Confessions of a theatrician. VIEWS, 15(5), 10-11. 
Pym, A. (1998). Method in translation history. Manchester: St. Jerome.

Razorenova, M. (1976, January 21). "Golos v naushnikah" [A voice in the headset]. Literaturnaja Gazeta, p. 4.

Raun, T. U. (1991). Estonia and the Estonians. Stanford, California: Hoover Institution Press.

Richardson, R. (2017). Sign language interpreting in theater: Using the human body to create pictures of the human soul. TranscUlturAl: A Journal of Translation and Cultural Studies, 9(1), 45-62.

Richardson, M., \& Thompson, D. (2018). Deaf people and the theatrical public sphere. Scottish Journal of Performance, 5(2), 11-33.

RID Standard on Interpreting for the Performing Arts. (2014). Retrieved from http://www.terptheater.com/wpcontent/uploads/2015/01/PerformingArts SPP.pdf?aea333\&x69122

Rocks, S. (2015). Theater interpreting. In F. Pöchhacker (Ed.), Routledge Encyclopedia of Interpreting Studies (pp. 417-418). London and New York: Routledge.

Romanovitch, I. (1971). Ugol otrazhenija [A viewpoint]. Teatr, 9, 63-68.

Seidman, I. (2006). Interviewing as qualitative research: A guide for researchers in education and the social sciences. New York: Teachers College Press.

Sibul, K. (2017). Teatrietenduste sünkroontõlkest eesti keelest vene keelde aastatel 1944-1991 [Simultaneous interpreting of theatre performances from Estonian into Russian from 1944 to 1991]. Methis: Studia humanora Estonica 19, 53-73.

Sibul, K. (2018). The development of interpretation in the context of Estonia's evolving statehood (Doctoral dissertation). Tartu: University of Tartu Press.

Sign on Stage, Illinois (1998). Doin' a Vanna, or one focus thrown is worth a thousand signs. VIEWS 15(5), 18.

Talts, L. (2000). Pärnu teatrilugu 1875-1991 [The history of theater in Pärnu 1875-1991]. Tallinn: Scriptum.

Teatriankeet [Theater questionnaire]. (1985). Teater. Muusika. Kino, 12, 48-56.

Tracy, S. J. (2013). Qualitative research methods. Chichester: Wiley-Blackwell.

TR Draamateatri etendused tõlgitakse vene keelde [Performances at the Tallinn State Drama Theater will be interpreted into Russian]. (1952, January 12). Sirp ja Vasar, p. 2.

Turner, G. H., \& Pollitt, K. (2002). Community interpreting meets literary translation: English-BSL interpreting in the theater. The Translator, 8(1), 25-48.

Uudised. Etendusasutused said toetust ühise kultuuriruumi arendamiseks [News. Theater companies got a grant to develop a common cultural space]. (2011). Retrieved from https://www.integratsioon.ee/juuli-2011-0\#2

Vare, S. (1999). Eesti hariduse keelepoliitika [The language police of education in Estonia]. In J. Viikberg (Ed.), Eesti rahvaste raamat (pp. 72-89). Tallinn: Eesti Entsüklopeediakirjastus.

Vene Teater. (2016, November 11). Vene Teater arendab multikultuurset teatriruumi [The Russian Theater develops multicultural theater space]. Retrieved from https://veneteater.ee/et/news/1119.html

Vene Teater (2017, February 27). SA Vene Teater kuulutab välja konkursi teatrietenduste sünkroontõlgi ametikohale [The Russian Theater advertises a competition to recruit a simultaneous interpreter to interpret theater performances]. Retrieved from https://veneteater.ee/news/1228.html

Vene teatri juht lahkub ametist [The director of the Russian Theater leaves office]. (2017, December 21). Postimees, p. 9. 
Vladimirova, G., \& Govorushko, E. (1987, July 3). Vastutus ja ambitsioonid [Responsibility and ambitions]. Sirp ja Vasar, p. 2.

Windle, K. (2011). The translation of drama. In K. Malmkjær \& K. Windle (Eds.), The Oxford Handbook of Translation Studies (pp. 153-168). Oxford: Oxford University Press.

Yantchek, S. (Ed.). (1998). Russkaja scena v Estonii [The Russian theater landscape in Estonia]. Tallinn: Avenarius.

Zetterberg, S. (2011). Eesti ajalugu [Estonia's history]. Tallinn: Tänapäev. 